Sikora Kamil, Wawryniuk Agnieszka, Luczyk Robert, Zwolak Agnieszka, Luczyk Marta, Nowicka Elżbieta. Patient care problems after a heart attack - clinical case study. Journal of Education, Health and Sport. 2019;9(11):194-199. eISSN 2391-8306. DOI http://dx.doi.org/10.12775/JEHS.2019.09.11.016

https://apcz.umk.pl/czasopisma/index.php/JEHS/article/view/JEHS.2019.09.11.016

https://zenodo.org/record/3553415

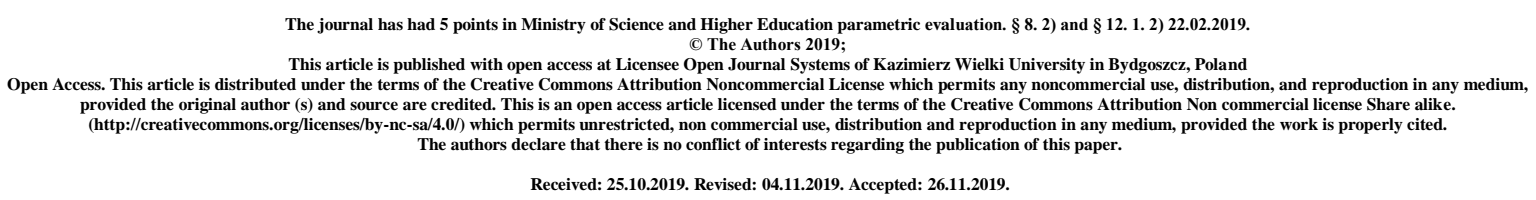

\title{
Patient care problems after a heart attack - clinical case study
}

\author{
Kamil Sikora ${ }^{1}$, Agnieszka Wawryniuk ${ }^{1}$, Robert Jan Luczyk ${ }^{1}$, \\ Agnieszka Zwolak ${ }^{1}$, Marta Luczyk ${ }^{2}$, Elżbieta Nowicka ${ }^{1}$
}

\author{
${ }^{1}$ Chair of Internal Medicine and Department of Internal Medicine in Nursing, Faculty of \\ Health Sciences, Medical University of Lublin \\ ${ }^{2}$ Department of Oncology, Department of Oncology and Environmental Health Care, \\ Faculty of Health Sciences, Medical University of Lublin
}

\section{SUMMARY}

Introduction. Half of deaths in Poland are caused by cardiovascular diseases. Such a high percentage causes them to rank first among the causes of death. According to the Polish Cardiac Society, acute coronary syndromes are the reason for hospitalization of 140,000 people annually, including myocardial infarction of 90,000 people each year [4]. In addition to sudden cardiac deaths, cardiovascular disease is also a major cause of hospitalization, as well as permanent or temporary disability, both physical and mental. This condition has consequences in the form of, among others, inability to work, which leads to the gradual development of social disability [7]. The multitude and variety of problems faced by patients determines the need to recognize and eliminate them.

The aim of the study is to present the required scope of patient care after myocardial infarction, based on individual case study.

A case report. A 82-year-old patient admitted to hospital after losing consciousness while working in the garden. The ECG showed myocardial ischaemia without visible ST segment elevation. Coronary angiography in the hemodynamic laboratory revealed stenosis of the left coronary artery, which was cleared by the introduction of a vascular stent. An individual care plan has been developed for the patient in accordance with the problems encountered. Conclusions. Patients after myocardial infarction have numerous nursing problems, which require professional actions performed by a nurse, which results in minimizing the problems and their consequences. Thanks to these activities, the patient and his immediate surroundings are prepared to continue providing care in the home environment.

Key words: myocardial infarction; nursing care; care problems; case study. 


\section{Introduction}

Myocardial infarction belongs to the so-called acute coronary syndromes, i.e. various forms of ischemic heart disease characterized by a rapid, sudden course, often resulting in sudden cardiac death. Almost $25 \%$ of US deaths are caused by a heart attack. In Poland, myocardial infarction affects approximately 100,000 persons annually, with about $60 \%$ of deaths occurring before admission to hospital, which indicates the priority of pre-hospital procedures [11]. This is a global problem for patients around the world, and is a major social dilemma. The disease in the acute or chronic stage results in a decrease in the patient's quality of life, general dissatisfaction, a decrease in sense of value. Studies have shown that patients after a myocardial infarction assess their health considerably worse than chronically ill people [1].

We can talk about myocardial infarction in the case of cardiomyocyte necrosis, sudden myocardial ischemia, most often caused by coronary artery occlusion, which results in myocardial necrosis [12]. Based on the electrocardiographic examination performed, we distinguish myocardial infarction with ST segment elevation (STEMI) and no ST elevation (NSTEMI). The first type of myocardial infarction may be accompanied by ECG pathological manifestations in the $\mathrm{Q}$ wave, if the ischaemia lasted more than 30 minutes. STEMI is the result of full coronary artery occlusion without collateral circulation for a minimum of 20-30 minutes, while NSTEMI type myocardial infarction is characterized by clinically significant but incomplete coronary lumen occlusion. Depending on the further course of ischemia, the appearance of pathological Q wave is much less frequent than in STEMI infarction. The above-mentioned division is one of the factors determining both pre-hospital and hospitalization [11].

The pathogenesis and etiology of all components of acute coronary syndrome is similar, and consists in most cases of complete or partial detachment of the atherosclerotic plaque from the wall of the blood vessel. A detached portion of the atherosclerotic plaque promotes the formation of a blood clot, which then causes complete closure or narrowing of the coronary artery lumen [9]. Myocardial infarction most often affects men over 55 and women over 45 [3].

The main symptom reported by patients who have suffered an infarction is coronary pain increased myocardial oxygen demand compared to reduced transport through atherosclerotic coronary arteries. The occurrence of coronary pain is often accompanied by increased stress or physical exertion. The characteristic features are the retrosternal location, and radiation to the neck, lower jaw, and left shoulder. In some patients, they may take "masks", eg epigastric pain, or not at all [2].

Factors determining the patient's belonging to risk groups are significant obesity (especially visceral type), low physical activity coefficient, and a diet containing a significant amount of saturated fatty acids (atherogenic diet). Other factors include smoking, hypertension, hypercholesterolemia, diabetes, blood clotting, genetic conditions, and stress [3].

The most important in the diagnosis of myocardial infarction is the performance of an ECG, and the determination of biochemical values of markers and enzymes such as AST, CK-MB mass, LDH, troponin I, myoglobin. The electrocardiographic features of necrosis include deepening of the Q wave, low R-wave amplitude, ST segment elevation, and pathological T wave. Patients after myocardial infarction are divided into the group with ST segment elevation and those without ST elevation. If there is no ST elevation and the concentration of markers of cardiomyocyte necrosis is elevated, it allows the diagnosis of myocardial infarction regardless of whether there has been a worsening of the $\mathrm{Q}$ wave. If the levels of the above markers in the serum are not elevated, we can talk about unstable angina. In patients with coronary pain, ST elevation, and increase in necrosis markers, we recognize a heart attack regardless of the presence of a Q wave. It is also important to note that in the first hours 
after the onset of an infarction, the ECG result may not be abnormal, so biochemical tests should always be performed $[8,6]$.

The treatment of patients in hospital conditions is once again influenced by the STEMI /NSTEMI division. The priority in treating patients with ST segment elevation is to restore and maintain flow in the occluded coronary artery as soon as possible. This is made possible by pharmacological procedures and those included in invasive cardiology, which enable mechanical unblocking of the artery. Management of myocardial infarction without ST elevation is based on observation and assessment of the risk of complete ischemia, on the basis of which a further treatment strategy is chosen [5].

The aim of the study is to analyze the patient's case in the immediate period after myocardial infarction, identify the problems associated with a given disease entity, and nurse activities to minimize the effects of their occurrence.

\section{A case report}

The study was conducted in April 2018 at the Independent Public Clinical Hospital No. 4 in Lublin. The cardiology clinic was chosen as the organizational subunit. The subject of the study was an 82-year-old patient referred to the ward in an emergency by a medical emergency team. The study, collected on the basis of interview, documentation analysis, observation and measurements, lasted for 3 days of hospitalization of the patient. The patient gave his informed consent to be examined and included in the work below, however due to data protection and professional secrets the patient's personal data has been changed or kept secret.

A 82-year-old patient, originally brought to the hospital emergency ward after falling, and temporarily losing consciousness while working in the garden. The patient with difficult contact, reported complaints of retrosternal chest pain. During the interview, the patient reported pre-existing episodes of atrial fibrillation and hypertension. Tomographic examination performed in the laboratory of the hospital emergency department revealed hypodense foci that may indicate earlier episodes of cerebral ischemia. After electrocardiographic examination, acute coronary syndrome was found, with no apparent ST segment elevation. Increased troponin I concentration in laboratory tests. Coronary angiography performed in the hemodynamic laboratory revealed stenosis of the left coronary artery, which was cleared by the introduction of a vascular stent. Further pharmacological treatment was applied, and then the patient was referred for observation to the intensive care unit of the cardiology, from where the next day he went to the cardiology clinic. Vital parameters on admission: RR: 190/83 mmHg; Heart rate: $92 \mathrm{u} / \mathrm{min}$; Temp: $37.2{ }^{\circ} \mathrm{C}$; Breath: 14 / min; Body weight: 45kg; Height: 140cm; BMI: 17.58. Physical examination of edema on the lower limbs. The patient's assessment used SCORE scales: 19\%, CSS: class II, NRS: 4 points. Holter ECG to monitor the work of the heart. Vital parameters were measured: RR 136/75; heart rate $84 \mathrm{u} / \mathrm{min}$; temperature $36.8^{\circ}$ C. Fasting glycaemia was $87 \mathrm{mg} \%$. Medication was given according to the doctor's order. Patient with logical contact, difficult due to hearing loss. He slept peacefully the night, no complications observed after coronary angiography. On the second day of hospitalization, the patient reported problems falling asleep last night, which was included in the nursing process. An echocardiographic examination was performed, which showed left ventricular hypertrophy. The patient took medication ordered by the doctor, he cooperated with the staff without any problems. Vital parameters were measured - within normal limits. Peripheral puncture was removed due to signs of vasculitis. During the last day of observation, there were no significant changes in the patient's state of health. Blood pressure slightly elevated (146/92), other parameters are normal. Due to persistent dizziness when standing up, the patient was advised to stay in bed. 
The medications taken are: Tertensiv SR, Aspirin 75mg, Calipoz, Vanatex HCT, Clexane 60 mg. The patient was classified into II care category and further nursing was planned, highlighting the following problems:

\begin{tabular}{|c|c|}
\hline Problem & Plan of works \\
\hline $\begin{array}{l}\text { Reduced tolerance } \\
\text { of physical effort } \\
\text { due to angina, a } \\
\text { history of } \\
\text { myocardial } \\
\text { infarction }\end{array}$ & $\begin{array}{c}\text { - Assessment of physical fitness of the patient. } \\
\text { - Increasing the intensity of effort while monitoring vital signs. } \\
\text { - Reduction of unnecessary physical exertion, adjustment of nursing } \\
\text { activities to the patient's abilities. } \\
\text { - Ensuring adequate conditions for sleep and rest. } \\
\text { - Introduction of gradual rehabilitation. } \\
\text { - Administration of drugs that improve coronary circulation. } \\
\text { - Use of easily digestible diet. }\end{array}$ \\
\hline $\begin{array}{l}\text { Difficulty falling } \\
\text { asleep due to } \\
\text { hospitalization }\end{array}$ & $\begin{array}{l}\text { - Daily assessment of patient's sleep quality. } \\
\text { - Instruct the patient to avoid sleeping during the day. } \\
\text { - Providing the patient with favorable conditions for falling asleep. } \\
\text { - Avoiding eating before bedtime. } \\
\text { - Recommendation to use relaxation exercises before bedtime. }\end{array}$ \\
\hline $\begin{array}{l}\text { Possibility of } \\
\text { cardiogenic shock } \\
\text { in a patient after } \\
\text { myocardial } \\
\text { infarction }\end{array}$ & $\begin{array}{l}\text { - Observation of patient's condition. } \\
\text { - Monitoring vital signs using a cardiomonitor. } \\
\text { - Conducting oxygen therapy. } \\
\text { - Providing intravenous access. } \\
\text { - Draw the patient's attention to reporting complaints. } \\
\text { - Participation in pharmacotherapy. } \\
\text { - Keeping patient records. } \\
\text { - Downloading material for diagnostic tests. }\end{array}$ \\
\hline $\begin{array}{c}\text { Patient's } \\
\text { knowledge deficit } \\
\text { about hypertension }\end{array}$ & $\begin{array}{l}\text { - Checking the current state of knowledge, identifying deficits. } \\
\text { - Explaining the essence of the disease to the patient. } \\
\text { - Presentation of normal blood pressure values. } \\
\text { - Teach the patient to measure blood pressure correctly. } \\
\text { - Exercise instruction at the intensity possible for the patient. } \\
\text { - Blood pressure monitoring. } \\
\text { - Keeping a blood pressure card. } \\
\text { - Participation in pharmacotherapy. }\end{array}$ \\
\hline $\begin{array}{c}\text { Risk of patient } \\
\text { malnutrition due to } \\
\text { nutritional errors }\end{array}$ & $\begin{array}{l}\text { - Assessment of the degree of patient malnutrition. } \\
\text { - Interview about the diet you have used so far. } \\
\text { - Allow consultation with a dietitian. } \\
\text { - Draw the patient attention to previous nutritional errors and ways to } \\
\text { correct them. } \\
\text { - Control of food intake by the patient. } \\
\text { - Application of nutritional treatment. }\end{array}$ \\
\hline
\end{tabular}




\begin{tabular}{|c|c|}
\hline $\begin{array}{l}\text { Difficult contact } \\
\text { with the patient } \\
\text { due to hearing loss }\end{array}$ & $\begin{array}{l}\text { - Loud, skillful communication of information to the patient. } \\
\text { - Encouragement to use a hearing aid. } \\
\text { - Use of non-verbal communication. } \\
\text { - Assessment of hearing loss. } \\
\text { - Providing recommendations to the therapeutic team regarding } \\
\text { communication with the patient. } \\
\text { - In the event of disagreement - writing information on a sheet of } \\
\text { paper. }\end{array}$ \\
\hline $\begin{array}{c}\text { Risk of patient } \\
\text { malnutrition due to } \\
\text { nutritional errors }\end{array}$ & $\begin{array}{l}\text { - Assessment of patient malnutrition according to the NRS scale. } \\
\text { - Interview about the diet you have used so far. } \\
\text { - Allow consultation with a dietitian. } \\
\text { - Draw the patient attention to previous nutritional errors and ways to } \\
\text { correct them. } \\
\text { - Control of food intake by the patient. } \\
\text { - Application of nutritional treatment [10]. }\end{array}$ \\
\hline
\end{tabular}

\section{Conclusions}

1. Nursing problems that have arisen in the examined patient are anxiety, constipation, exercise intolerance, hearing loss, difficulty falling asleep, fainting, knowledge deficit, swelling, as well as the risk of other inconveniences, are only part of all difficulties that may affect patients after myocardial infarction.

2. A patient after a myocardial infarction requires a variety of nursing activities depending on individual needs, described in detail in the chapter on nursing a patient after a heart attack. 3. The priority in caring for patients should be to minimize the risk of problems, which is possible thanks to the educational activities carried out by the nurse. As a person who is closest to the patient and his family, he is a kind of authority and a specialist who provides them with the necessary knowledge and skills.

4. By implementing the measures provided for patient care after a heart attack in a reliable and professional manner, the nurse is able to provide sufficient care for the patient during his hospitalization, as well as prepare him for later self-care

5. Informing the patient about existing problems and those that may arise in the near future, as well as presenting ways of overcoming them creates opportunities for the patient to cope after leaving the hospital, and provides knowledge, skills and motivation to constantly improve the quality of life by the patient and his immediate surroundings. 


\section{Bibliography}

1. Borowiak E, Rosiak K, Kostka T.: Comparative analysis of the effect of diabetes and undergone heart attack on the patients' quality of life. Nursing Problems / Problemy Pielęgniarstwa; 2009; 17(2):86-91.

2. Doboszyńska A.: Objawy Chorób Wewnętrznych. Warszawa: Wydawnictwo Lekarskie PZWL; 2013.

3. Herold G, Duława J.: Medycyna Wewnętrzna. Warszawa: Wydawnictwo Lekarskie PZWL; 2008.

4. Horoch A, Kulik T, Pacian A.: Zdrowie Publiczne. Warszawa: Wydawnictwo Lekarskie PZWL; 2015.

5. Januszewicz W, Kokot F, Bartnik W.: Interna. Warszawa: Wydawnictwo Lekarskie PZWL; 2006.

6. Jurkowska G, Daniluk J.: Zarys Chorób Wewnętrznych Dla Studentów Pielęgniarstwa. Lublin: Wydawnictwo Czelej; 2005.

7. Karski J, Chromiński Z. Promocja Zdrowia. Warszawa: Ignis; 1999.

8. Kokot F, Bilikiewicz A.: Diagnostyka Różnicowa Objawów Chorobowych. Warszawa: Wydawnictwo Lekarskie PZWL; 2007.

9. $\quad$ Kokot F, Chwalińska-Sadowska H.: Choroby Wewnętrzne. Warszawa: Wydawnictwo Lekarskie PZWL; 2006.

10. Kózka M, Płaszewska-Żywko L, Cepuch G.: Diagnozy i Interwencje Pielegniarskie. Warszawa: Wydawnictwo Lekarskie PZWL; 2010.

11. Mandecki T, Cieśliński A.: Kardiologia. Wydawnictwo Lekarskie, PZWL; Warszawa 2005.

12. Widomska-Czekajska T, Górajek-Jóźwik J, Bernat K.: Encyklopedia Dla Pielęgniarek I Połoznych. Warszawa: Wydawnictwo Lekarskie PZWL; 2010. 